Research Article

\title{
Price Strategy of Competitive Supply Chain Based on Bank Financing
}

\author{
Jing Gao \\ Finance Section, Jiangsu Normal University, Xuzhou, Jiangsu 221116, China \\ Correspondence should be addressed to Jing Gao; 6020140071@jsnu.edu.cn
}

Received 4 November 2019; Accepted 28 December 2019; Published 13 April 2020

Academic Editor: Massimiliano Ferrara

Copyright (@) 2020 Jing Gao. This is an open access article distributed under the Creative Commons Attribution License, which permits unrestricted use, distribution, and reproduction in any medium, provided the original work is properly cited.

\begin{abstract}
In the traditional single-chain supply chain literature research, it is assumed that enterprises in the supply chain system have enough working capital. However, in practical management practice, enterprises are often faced with capital shortage, poor operation, and other related risks. In this paper, the price strategy of competitive supply chain based on bank financing is studied when many retailers are short of funds in the competitive environment. It is found that once the market share among retailers is fixed, the wholesale price of suppliers and the selling price of retailers will gradually increase with the increase of competition intensity, regardless of whether the retailer has financial constraints or not. The greater the competition intensity among retailers is, the better the expected profit of each member of the supply chain and the system will be. Finally, with the help of numerical analysis, the validity of the conclusion is depicted and verified. The relevant conclusions enrich and develop the financing theory of competitive supply chain, providing a strong practical reference value for the fund risk management of supply chain enterprises in the competitive environment.
\end{abstract}

\section{Introduction}

With the rapid development of economic globalization, the global retail industry is also undergoing powerful changes. The rapid expansion of the scale of retailers and the significant improvement of the retail market gathering have presented challenges to the traditional dominant power of the supply chain. In the past, the discourse power is completely monopolized by the manufacturers and other enterprises. Now, with the implementation of strategies such as resource acquisition, combination of energetic enterprises, and regional competitive advantage, retailers are becoming more and more competitive in the market economy [1]. Changes in the competitive environment require retailers to have more capital to cope with the ever-changing market environment, such as foreign famous retailers (Walmart, Carrefour, etc.). They have a larger amount of capital. Compared with foreign countries, domestic retailer enterprises (Gome, Suning, Trust-Mart, and Red Flag supermarket) often have stronger financial needs for operation because of insufficient funds [2].
During the operation of a company, especially at the beginning of the establishment of a new company, decision makers are often faced with circulating fund constraints. Recently, there was a detailed story about Pen Again, a company that Wall Street had just created, which sought bankruptcy protection due to a lack of funds in its operations, but also found itself strapped for cash, which led the company to raise local debt [3]. Similarly, in China, Midea tend to invest a certain amount of money to retailers or manufacturers in the off-season to ensure smooth ordering and sales channels. Other domestic retailers, such as Industrial and Commercial Bank of China, use their own credit ratings to raise capital at designated banks.

In fact, many enterprises in a single-chain supply chain will choose to raise funds from banks once they have capital constraints [4]. The reason why banks are willing to give loans to enterprises is that financially constrained enterprises pledge available resources such as stock goods, warehouse receipts, purchased goods, or accounts receivable to banks [5]. If the company fails to repay the loan on time, the bank will auction 
off the collateral to reduce the bank's bad debts. Buzacott and Zhang [6] introduced asset-based financing into production decision-making earlier. By establishing a Stackelberg game model between banks and retailers, they found that comprehensive consideration of production and financing decision making can play an important role in entrepreneurial enterprises. However, there are still many horizontal enterprises in the same industry, such as Australian living retail supermarkets Coles and Woolworths and Chinese home appliance retail industries such as Five-star, Gome, and Suning. They all have the same or different product suppliers or manufacturers, easily forming a multichain competitive product sales environment. If vertical partners in multiple chains are short of capital, can they still choose to raise capital from banks? Does financing affect the price decisions and expected profits of supply chain members? How does the intensity of competition affect the price decisions and expected profits of supply chain members? These are all problems we need to solve.

In this study, we will build two exclusive supply chains, each consisting of a manufacturer and a retailer. In one case, two retailers are full funds; in the other case, two retailers are short funds. There is market competition between the two retailers, who sell alternative products. They are both rational and can maximize their expected profits. Under different competition intensities, the manufacturer's wholesale price and the retailer's selling price are different when the retailer has capital constraint or not. In addition, this study will also explore the influence of competition intensity between two alternative products on price decision and expected profit of supply chain members. Therefore, our research contributes to the financing expansion of enterprises in the competitive environment and it is different from previous studies in the following aspects.

(1) Two price decision models of competitive supply chain are established, and the optimal price strategy of each member is deduced, and the influence of competition intensity on this decision making is analyzed.

(2) When external banks are financing, compared with expected profits of members and systems of competitive supply chain without capital constraints, the effects of competition intensity and pricing strategy on expected profits of members and systems of competitive supply chain are analyzed.

The rest of this paper is organized as follows. Section 2 presents the literature review. In Section 3, the paper briefly introduces the practical problems and some basic assumptions. In Section 4, it establishes the financing decision model of competitive supply chain banks with or without capital constraints and gives the optimal pricing strategy of each supply chain member through reverse induction. Through numerical analysis, the relationship between wholesale price, sales price, expected profit, and parameter variables (competition intensity) is given in Section 5. Section 6 gives the conclusion of the study and its contribution and the shortcomings of this paper and research directions in the future.

\section{Literature Review}

The relevant literature on price decision of competitive supply chain based on bank financing mainly focuses on two aspects: one is the research on bank financing of enterprise capital constraint in supply chain system and the other is the research on operation decision of supply chain in competitive environment.

\subsection{Bank Financing of Enterprise Capital Constraint.} Considering that demand is uncertain, Buzacott and Zhang [6] discussed and analyzed the relationship between financing ratio and enterprise operation, and found that financing ratio is not always conducive to enterprise efficiency. Based on certain conditions, $\mathrm{Xu}$ and Zhang [7] studied two strategies of banks, namely, providing financing support and goods assistance to undercapitalized retailers and found that both the two ways can ensure smooth operation of the supply chain. In the medical supply chain, especially in the medical aid transportation of blood, the cost of bank financing affects the transportation efficiency of the medical supply chain [8]. Dada and $\mathrm{Hu}$ [9] discussed a capital constraint newsboy model that can be borrowed from banks, and the results showed that the optimal ordering decision of newsboys would be affected by capital constraint. When the cost of bank borrowing was not too high, retailers would use loans to purchase products. Chen et al. [10] held that two-level supply chain consists of a retailer and a supplier structure model, and they studied the operation decision of the supply chain and financial decision under the two-level structure. Zhang and Li [11] studied how to make decision on the production quantity and the loan amount when enterprise fund is limited and must borrow money from banks. They found that if the loan value for inventory pledge given by banks is lower, the enterprise can apply for a loan from the bank only in the case of funds shortage; if the value of the loan is high, the company is likely to retain some funds and continue to replenish inventory with loans. Raghavan and Mishra [12] considered and established a twotier supply chain structure model consisting of a single retailer and a single supplier. Once any member of the supply chain sees signs of capital shortage, the supply chain will choose joint financing decision. Lai et al. [13] studied the influence of loan financing, reservation mode, consignment mode, and mixed mode of external financial institutions on the performance of supply chain system. Lee and Rhee [14] studied that the retailers can adopt two kinds of methods of deferring capital constraints and external financing to solve the problem of insufficient funds. Through the analysis and research of each kind of model, it was found that the wholesale price contract could not make the supply chain coordination in two modes, and supply chain repurchase and revenue sharing contract can coordinate the supply chain in the delayed payment mode.

Kouvelis and Zhao [15] studied that retailers with capital constraints can adopt external financing strategy, that is, they can raise funds from banks, and found that the amount of their own funds and the value of collateral have influences 
on the optimal financing and ordering decisions of retailers. Raghavan and Mishra [16] paid attention to the problem of joint financing decision making under the framework of Stackelberg game when considering the capital constraint of both retailers and suppliers. They found that external financing of supply chain benefits not only banks, but also retailers and manufacturers if enterprises in the supply chain have insufficient funds. Jing et al. [17] studied that due to the need to pay high wholesale prices, commercial banks have more advantages in financing than internal financing credit between supply chains. Yu and Luo [18] studied that the retailer who has insufficient fund subsidizes or delays the payment of suppliers' money to financial institutions, depending on the expected cost of the retailer, and it gave the conditions for the retailer to choose insufficient financing or delayed payment. Lu et al. [19] established the decisionmaking model of accounts receivable financing among commercial banks, suppliers, and core enterprises under the game framework, finding that accounts receivable financing could achieve Pareto optimization in the supply chain. Ariel et al. [20] studied the production inventory model under different financing modes and found that cash flow under operating capital constraints is not sensitive to the impact of short-term debt.

Once the required working capital target rapidly expands, cash flow is more sensitive to short-term debt operation. Yan and Sun [21] designed a supply chain financial system composed of manufacturers, retailers, and commercial banks. Considering the credit line and bankruptcy probability of retailers, Yan and Sun proposed the optimal financing rate of commercial banks, the optimal ordering decision of retailers, and the optimal wholesale price of manufacturers. Yan and other researchers [22] established a multisubject game framework in which commercial banks are the game leaders and manufacturers are subleaders by constructing a supply chain system consisting of a single manufacturer, a single fund-constrained retailer, and a bank and studied the joint financing decision problem of supply chain in the financial system. It was found that different interest rates and credit lines will affect the operation of supply chain. Wang et al. [23] studied the optimal strategy of receivables financing for suppliers with fund gap in the supply chain financial system under the implicit equity, and the results showed that suppliers considering the implicit equity could easily obtain credit from banks at a relatively low financing cost.

Kouvelis and Zhao [24] considered the financing decision problem of supply chain with bankruptcy cost and gave the equilibrium solution of order quantity and wholesale price. Peng [25] studied the optimal financing amount and operation strategy under the uncertain supply chain accounts receivable mortgage financing model. The research shows that when the risk of uncertain output is larger, the production enthusiasm of suppliers under the mode of accounts receivable financing is higher than that of sufficient funds. Xu and Ma [26] considered a two-tier supply chain consisting of two competing suppliers and one retailer and a third-party logistics company (3PL) that provides purchasing and logistics services and provides financing to suppliers when they are constrained by capital, establishing a 3PL financing decision model and a profit model for retailers and suppliers. Lin and $\mathrm{Xu}$ [27] studied how to achieve coordination through contracts in the secondary supply chain where the retailer is the dominant supplier and the supplier has limited funds of their own. The study showed that when the supplier's own funds are greater than or equal to a critical value, supply chain coordination can be achieved through option contracts under advance financing.

The literature for bank financing research is based on the existence of capital constraints of enterprises in the singlechain supply chain and did not focus on the capital constraint conditions of enterprise in competition environment, without considering the intensity of competition, bank financing, and other factors affecting pricing decision of the supply chain members. It did not consider the intensity of competition, pricing strategies, etc., thus affecting supply chain members and the system's expected profits.

\subsection{Supply Chain Operation Decision in Competitive} Environment. Chain-to-chain competition mainly refers to the direct or indirect competition between multiple manufacturers and professional intermediaries. This kind of model considers that multiple manufacturers compete with the final customers through professional intermediaries. McGiure and Staelin [28] analyzed the dominant vertical structure of two manufacturers and two exclusive retailers according to the determined linear demand function, finding that the decentralized structure strategically avoided the possible cruel price competition between manufacturers. Later, scholars expanded the research on chain and chain competition. Based on the competitive supply chain model, Moorthy [29] examined the impact of strategic interaction on manufacturers' channel structure decision making. The conclusion shows that the implementation of decentralization strategy lies in the coupling relationship between demand dependence and strategic dependence, not in the substitution of two products. Trivedi [30] studied three channel equilibrium structures consisting of two competitive manufacturers and two competitive retailers (i.e., integrated or decentralized chain-to-chain competition structure and a manufacturer-to-two retailers cross-competitive supply chain). Boyaci and Gallego [31] examined the effects of service level and inventory cost on the vertical coordination of competitive supply chains (there are three kinds of situations that two supply chains are uncoordinated, two supply chains are coordinated, one supply chain is coordinated, and the other supply chain is uncoordinated). The study found that coordination is the dominant strategy for both supply chains, but just like the prisoner's dilemma, the performance of the supply chain in the case of coordination is often lower than that in the case of incoordination, but the customer can always benefit from coordination. Ha and Tong [32] based on the chain and chain competition model of manufacturer's diseconomies of scale investigated the impact of diseconomies of scale, competition intensity, and information accuracy on supply 
chain performance in vertical information sharing. It was found that when the competition between supply chains is quantitative competition, if the scale of production is not economic or the horizontal competition is weak or the information of at least one retailer is not accurate, the vertical information sharing will benefit the supply chain.

Xiao and Yang [33] constructed a manufacturer with information disclosure mechanism corresponding to a retailer's supply chain and an integrated competitive supply chain. The research shows that when the risk-cost sharing ratio of manufacturer is very high (low), the optimal wholesale price of retailer with high risk aversion is higher (low) than that of retailer with low risk aversion. Lu and Zhu [34] analyzed two models of supply chain coordination, noncoordination, and only one supply chain coordination in quality and price competition and found that all supply chain profits may be less than those in uncoordinated supply chain, i.e., prisoner's dilemma, but customers can always benefit from them. Xu and Sun [35] aimed at two supply chain models consisting of single manufacturer and single retailer, respectively. The results show that coordination is the dominant strategy in supply chain competition, but the performance of both supply chains is worse than that of uncoordinated supply chains. Ha et al. [36] studied whether to invest in vertical information sharing in competitive supply chain when using menu contract and linear price contract, respectively. The conclusion shows that when using menu contract, without information sharing, sales will be reduced. If the investment cost of information sharing is very low, information sharing is a dominant strategy.

Ai et al. [37] calculated the performance of two competitive supply chains in three situations: wholesale price contract without sharing market demand forecasting information, revenue sharing contract with sharing market demand forecasting information, and revenue sharing with sharing market demand forecasting information only. The competitive strength and price of products were analyzed. The influence of product competition intensity, price risk, and alliance ratio on information sharing and revenue sharing contract selection is analyzed. $\mathrm{Wu}$ [38] discussed the chain-to-chain Nash bargaining game model based on price competition and promotion effort level. When price and promotion efforts depend on demand, manufacturer-led supply chain and integrated supply chain strategy are a special case in Nash bargaining contract. Xiao et al. [39] discussed the coordination and equilibrium mechanism of the supply chain with MTO strategy in the presence of price and advance competition and designed a contract to achieve coordination of the supply chain in the case of two competitive supply chains, namely, decentralized distribution channel and direct distribution channel. Fang and Shou [40] examined the decision-making equilibrium and contract design of supply chain with Cournot competition under stochastic output. The effects of uncertain supply level and competition intensity on balanced order quantity, contract design, and structure selection were obtained.

Amin-Naseri and Khojasteh [41] constructed a price competition model in the uncertain demand environment.
Each supply chain is composed of risk-neutral manufacturers and risk-averse retailers. The equilibrium analysis is made on the two structures of the manufacturer as the dominant player and the retailer as the dominant player. Zhang et al. [42] extended the Salop ring city model in the traditional retail market with competition of similar existing products and studied the pricing strategy of dual-channel supply chain for alternative products in the e-commerce environment. It was found that the degree of product substitution has a positive impact on the pricing and retail channel demand of alternative products, but a negative impact on the demand and pricing of existing products. Sun and Qiao [43] used the Stackelberg game model to analyze the price strategy of manufacturers and retailers under the competition of channel services based on the different perceptions of consumers about channel service level and channel price and drew the conclusion that channel price is affected by service level, service cost coefficient, consumer service, and channel price. Price affects the channel structure of supply chain.

Li et al. [44] constructed a decision-making model of supply chain pricing form and studied the choice between linear pricing, two-part charging system, and resale price maintenance under different conditions. It was found that the manufacturer's choice of optimal pricing form is related to the regulatory environment of resale price maintenance, the degree of coordination of resale price maintenance pricing, and the degree of product substitution. Zheng et al. [45] constructed a price competition model consisting of one manufacturer and two competing retailers and found that with the increase of retailer competition, product price increases, while deferred service price increases only under the decentralized model. Wei et al. [46] studied the pricing decision of a two-channel supply chain consisting of a single manufacturer and a multicompetitive retailer under Bertrand competition, Stackelberg competition, and centralized decision making. It was found that the profits of the whole supply chain and its members decrease with the increase of the number of retailers and price sensitivity under Bertrand competition, Stackelberg competition, and centralized decision.

All the studies on the operation of competitive supply chain mentioned above assume that enterprises do not have operational capital constraints, while in real life, capital shortage always exists. When an enterprise is short of funds, it cannot purchase the required amount of products, which will affect the operation of upstream and downstream enterprises and ultimately damage the overall interests of the supply chain.

Therefore, based on the above two aspects of the literature review, we mainly innovate in the following two points: first, compared with capital constraints of supply chain enterprise not existing in other literature, in real life, the shortage of funds is always present. We assume that retailers have the risk of capital constraints, which is more in line with the risk characteristics of general facts. Secondly, the analysis of pricing decisions of underfunded retailers and the impact of competition intensity among retailers on supply chain members and system expected profits is 
another innovation point. It will have more practical significance to study the competitive retailers with the risk of capital constraints and the pricing strategy in the face of the real problems such as insufficient funds, providing more guidance for the effective operation of emerging companies and start-ups in the competitive environment.

\section{Problem Description and Hypotheses}

This paper considers two exclusive competitive supply chain systems, each of which is a subsystem consisting of a single manufacturer (M1 and M2) and single retailer (R1 and R2), including two kinds of circumstances: a situation in which two retailers are not financially constrained and a situation in which two chains of two retailers have capital constraints. There is market competition between the two retailers, and the products sold in the market can be replaced. They are both rational and risk-neutral, taking the expected profit maximization as the decision-making goal. The pricing decision-making model of competitive supply chain in two cases is shown in Figure 1.

The market demand function of the product is

$$
\begin{aligned}
& d_{1}=t \cdot a-p_{1}+b \cdot p_{2}, \\
& d_{2}=(1-t) \cdot a-p_{2}+b \cdot p_{1},
\end{aligned}
$$

where $t$ is the market share of products sold by retailer 1 , $1-t$ is the market share of retailer 2 products, $b$ is the competition intensity among retailers, and $a$ is the potential market share. Suppose that the manufacturer's production costs are all zero.

When the retailers in the two chains have capital constraints, their initial capital are $B_{1}$ and $B_{2}$, respectively, they will choose to borrow money from external bank $\mathrm{B}$, and the financing interest rate of the bank is $r\left(r>r_{f}\right)$, in which $r_{f}$ is the risk-free interest rate. $M M$ means that the retailers in the two chains have no financial constraints, and they conduct supply chain operation with price competition to meet the market demand. $B B$ indicates that the retailers in both chains have financial constraints, and they take loans from banks and conduct supply chain operation with price competition to meet the market demand; $w^{*}, p^{*}, M M^{*}$, and $B B^{*}$, respectively, represent the optimal wholesale price, sales price, and expected profit of MM and BB.

\section{Model Establishment and Analysis}

4.1. The Two Competing Retailers without Financial Constraints. In this case, the competing retailers 1 and 2 in the two supply chains have no financial constraints, and they make supply chain decisions on price competition. The specific game sequence is as follows: firstly, the upstream manufacturer gives the most favorable wholesale price based on its maximum profit; secondly, the downstream retailer gives the market selling price based on the wholesale price provided by the manufacturer in the respective chain to maximize its profit and meet the market demand. Therefore, the expected profit of manufacturers and retailers is, respectively:

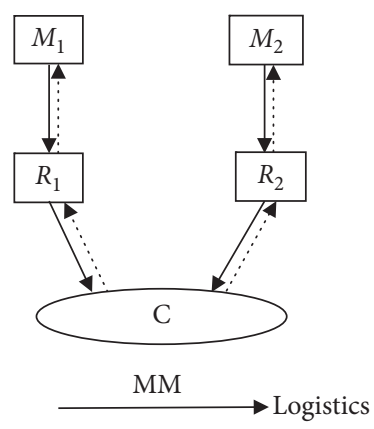

(a)

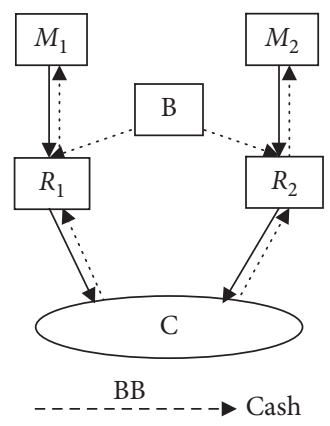

(b)
FIgURE 1: Competitive supply chain model with or without capital constraint.

$$
\begin{aligned}
M_{i} & =w_{i} d_{i}, \quad i=1,2, \\
R_{i} & =\left(p_{i}-w_{i}\right) d_{i}, \quad i=1,2 .
\end{aligned}
$$

According to the backward induction, we first find its sales price according to the retailers' maximization profit. The sales price at this time is a function containing the wholesale price. Then, substitute the expression of selling price into the expected profits expression of manufacturers, namely, (1). And the manufacturer's wholesale price can be obtained. Then, by substituting the wholesale price function into the expression of selling price, the sales prices of retailers can be obtained. The wholesale price of the manufacturer and the selling price of the retailer in the two chains are, respectively:

$$
\begin{aligned}
& w_{1}^{M M^{*}}=\frac{a s_{1}(t, b)}{\left(2 b^{2}-4+b\right)\left(2 b^{2}-4-b\right)}, \\
& w_{2}^{M M^{*}}=\frac{a s_{2}(t, b)}{\left(2 b^{2}-4+b\right)\left(2 b^{2}-4-b\right)}, \\
& p_{1}^{M M^{*}}=\frac{2 a\left(b^{2}-3\right) s_{1}(t, b)}{\left(b^{2}-4\right)\left(2 b^{2}-4+b\right)\left(2 b^{2}-4-b\right)}, \\
& p_{2}^{M M^{*}}=\frac{2 a\left(b^{2}-3\right) s_{2}(t, b)}{\left(b^{2}-4\right)\left(2 b^{2}-4+b\right)\left(2 b^{2}-4-b\right)},
\end{aligned}
$$

and $s_{1}(t, b)=2 t b^{3}-2 b^{3}-3 t b^{2}+6 b-6 t b+8 t$ and $s_{2}(t, b)$ $=-2 t b^{3}-3 b^{2}+3 t b^{2}+6 t b-8 t+8$.

Substitute (5)-(8) types, respectively, into the expected profits expression of manufacturers and retailers, namely, substitute (5)-(8) types into (3) and (4) types, respectively, so that the optimal expected profit of each member of the two supply chains can be obtained (as a result of the expected profit function expression is more complex, no specific expression is given here; in Section 5, we use numerical analysis to observe and describe the relationship between the expected profit and the intensity of competition).

Proposition 1. Under the retailer in the two supply chains has no capital constraint, when the market share $0<t<1 / 2$, 
$p_{1}^{M M^{*}}<p_{2}^{M M^{*}}, \quad w_{1}^{M M^{*}}<w_{2}^{M M^{*}}$, When market share $1 / 2<t<1, p_{1}^{M M^{*}}>p_{2}^{M M^{*}}, w_{1}^{M M^{*}}>w_{2}^{M M^{*}}$.

Proof. See the Appendix.

Proposition 1 indicates that the size relationship between the retailer's selling price and the manufacturer's wholesale price in two chains is independent of the competition intensity and mainly depends on the market share of products in each chain. The smaller the market share of products in the first chain of retailer 1 and manufacturer 1 is, the lower the selling price and wholesale price of products in the second chain of competitor retailer 2 and manufacturer 2 is correspondingly. On the contrary, the larger the market share of products in the first chain of retailer 1 and manufacturer 1 is, the higher the selling price and wholesale price of products in the second chain of competitor retailer 2 and manufacturer 2 is. For two competing retailers with no financial constraints, the chain having the largest market share will have stronger pricing power. The intensity of competition between retailers only affects the selling price of each retailer and the wholesale price of manufacturers, but it has no effect on the relationship between the selling price of two retailers and the wholesale price of two manufacturers. Next, the relationship between the selling price of retailers and the wholesale price of manufacturers and the intensity of competition can be further observed, and then Proposition 2 is established.

Proposition 2. The sales price of retailer 1 and retailer 2 is an increasing function of competition intensity, that is, the sales price will gradually increase with the increase of competition intensity. The wholesale price of manufacturer 1 and manufacturer 2 is also an increasing function of competition intensity, that is, the wholesale price will gradually increase with the increase of competition intensity.

The same method used in Proposition 1 can prove Proposition 2.

4.2. Both Capital-Constrained Retailers Adopt Bank Financing. In this case, the competing retailer 1 and retailer 2 in the two supply chains have capital constraints. Assuming the initial capital is $B_{1}$ and $B_{2}$, abbreviated as $B_{i}(i=$ $1,2)$ is for short. They all choose to borrow money from external banks. The financing interest rate of the bank is $r$ $\left(r>r_{f}\right)$, in which $r_{f}$ is the risk-free interest rate. Then, they make supply chain decisions of price competition. Specific game order is as follows: first of all, the upstream manufacturers give their best wholesale price according to their own maximum profit. Then, the downstream retailers give the market sales price to maximize their own profit according to the wholesale price provided by the manufacturer in their chain, in which the insufficient funds are financed from the bank, meeting the market demand. Therefore, the expected profit of manufacturers and retailers is, respectively:

$$
\begin{aligned}
& M_{i}=w_{i} d_{i} \\
& R_{i}=\left(p_{i}-w_{i}\right) d_{i}-\left(w_{i} d_{i}-B_{i}\right) r .
\end{aligned}
$$

The same method used in Section 4.1 can be used. The wholesale prices of manufacturers and the selling prices of retailers on the two chains are

$$
\begin{aligned}
& w_{1}^{B B^{*}}=\frac{a s_{1}(t, b)}{\left(2 b^{2}-4+b\right)\left(2 b^{2}-4-b\right)(1+r)}, \\
& w_{2}^{B B^{*}}=\frac{a s_{2}(t, b)}{\left(2 b^{2}-4+b\right)\left(2 b^{2}-4-b\right)(1+r)}, \\
& p_{1}^{B B^{*}}=\frac{2 a\left(b^{2}-3\right) s_{1}(t, b)}{\left(b^{2}-4\right)\left(2 b^{2}-4+b\right)\left(2 b^{2}-4-b\right)}, \\
& p_{2}^{B B^{*}}=\frac{2 a\left(b^{2}-3\right) s_{2}(t, b)}{\left(b^{2}-4\right)\left(2 b^{2}-4+b\right)\left(2 b^{2}-4-b\right)} .
\end{aligned}
$$

Proposition 3. Under two retailers have capital constraints and raise capital from external bank, when the market share $t \in(0,(1 / 2)), p_{1}^{B B^{*}}<p_{2}^{B B^{*}}$ and $w_{1}^{B B^{*}}<w_{2}^{B B^{*}}$. When market sharet $\in((1 / 2), 1), p_{1}^{B B^{*}}>p_{2}^{B B^{*}}$ and $w_{1}^{B B^{*}}>w_{2}^{B B^{*}}$.

A method similar to Proposition 1 can prove that Proposition 3 is true.

Proposition 3 shows that when two retailers in two chains have capital constraints and conduct external bank financing, the relationship between the retailer's selling price and the manufacturer's wholesale price in two chains has nothing to do with their competitive intensity, but mainly depends on the market share of products in each chain. The market share of the first supply chain is small, and the selling price and wholesale price are low. The market share of the second supply chain is large, and the selling price and wholesale price are high. For two competing retailers with no financial constraints, the chain having the larger market share will have stronger pricing power. The intensity of competition between retailers only affects the selling price of each retailer and the wholesale price of manufacturers, but it has no effect on the size relationship between the selling price of two retailers and the wholesale price of two manufacturers. Next, the relationship between the selling price of retailers and the wholesale price of manufacturers and the intensity of competition can be further observed. Thus, Proposition 4 is true.

Proposition 4. When two retailers have capital constraints and adopt external bank financing, the sales price of retailers 1 and 2 is an increasing function of competition intensity, that is, the sales price will increase gradually with the increase of competition intensity. The wholesale price of manufacturer 1 and manufacturer 2 is also an increasing function of competition intensity, that is, the wholesale price will gradually increase with the increase of competition intensity.

The same method used in Proposition 1 can prove Proposition 4. 
When two retailers have capital constraints and adopt external bank financing, the conclusions of Propositions 3 and 4 are same as those of Propositions 1 and 2. However, what is the price decision and size relationship of each member in a competitive supply chain when there is no capital constraint or there is capital constraint and external bank financing is adopted? Therefore, Theorem 1 holds.

Theorem 1. When the retailer with capital constraints adopts bank financing, the external bank financing mode has no impact on the retailer's sales price, that is, $p_{1}^{M M^{*}}=p_{1}^{B B^{*}}$, $p_{2}^{M M^{*}}=p_{2}^{B B^{*}}$; however, the wholesale price of manufacturers in the case of external bank financing has a great change compared with the wholesale price of manufacturers in the case of no capital constraint. The wholesale price of manufacturers in the first chain increases, while the wholesale price of manufacturers in the second chain decreases, that is, $w_{1}^{M M^{*}}<w_{1}^{B B^{*}}, w_{2}^{M M^{*}}>w_{2}^{B B^{*}}$.

Theorem 1 shows that when the retailer adopts external bank financing due to capital constraints, the retailer's sales pricing will not change due to the pressure of bank financing cost, mainly because the market environment has a greater recognition of the product. In other words, if the retailer takes financing because of insufficient funds and increase the purchase cost of retailers, it is not feasible for retailers to choose to increase the sales price to increase profits. As a result, retailers can only maintain the original product sales prices unchanged and reduce their profits. Retailers get lower profits than that without money constraints.

Compared with the selling price, the wholesale price of manufacturers will change. Bank financing will increase the wholesale price of manufacturers in the supply chain where the products occupy less market share and decrease the wholesale price of manufacturers in the supply chain where the products occupy more market share. According to general economic principles, the fewer products in the wholesale market are, the higher the price of product is. On the contrary, the more products there are in the wholesale market, the lower the price will be. Faced with retailers with financial constraints, manufacturers in the two chains choose different wholesale pricing strategies. On the contrary, the products with less market share are priced higher, and the products with more market share are priced lower. Once the downstream retailers have financial constraints, the upstream enterprises in the supply chain with less market share will raise the price, leading to the loss of some retailers in the wholesale market, and then manufacturers will find new downstream retailers to replace the original retailers. On the contrary, the upstream enterprises in the supply chain with more market shares will lower the price, leading some retailers in the wholesale market to turn to the upstream enterprises, and then manufacturers will expand the downstream retailers in the chain.

\section{Numerical Analysis and Discussion}

Numerical analysis is helpful to better understand and characterize the influence of competition intensity on the optimal pricing strategy of two competing supply chains and the expected profit of each member and system of the supply chain. We assume that the market share is 100 , i.e., $a=100$, and the market share of retailer 1 is $t$. It has three cases, i.e., $0.1,0.3$, and 0.5 . The market share of retailer 1 is gradually increasing, while the market share of retailer 2 is $0.9,0.7$, and 0.5 , which are gradually decreasing, and finally the market is evenly divided. On the contrary, the market share $t$ of retailer 1 is $0.9,0.7$, and 0.5 , and the market share of retailer $R_{1}$ is gradually decreasing, while the market share of retailer 2 is $0.1,0.3$, and 0.5 , which are gradually increasing, and it is finally in a state of equal market. Therefore, the market shares of $0.1,0.3$, and 0.5 can only be taken as examples. When there are capital constraints on both chains, they all seek financing from external banks. At this time, the bank financing interest rate is 0.02 , that is, $r=0.02$, and the initial capital of retailer 1 is 1000 , and the initial capital of retailer 2 is 1500 , that is, $B_{1}=1000, B_{2}=1500$.

Figure 2 shows that in different market share environments, whether there are no financial constraints in the two competitive supply chain systems or there are capital constraints and external bank financing are taken, the upstream manufacturer's wholesale price in their respective chain is an increasing function of the intensity of competition between retailers and wholesale price increases with the increase of the competition intensity. For different market shares, the wholesale price of manufacturer 1 will increase with the increase of market share under certain competition intensity between retailers. Pricing will be higher and higher. Under certain competition intensity between retailers, the wholesale price of manufacturer 2 will decrease with the increase of market share, and the price becomes increasingly low. Finally, when two manufacturers share the market share equally, the wholesale price of two manufacturers tends to be the same. For retailers with no capital constraints and with capital constraints and taking bank financing, it was found that in a lower share market environment (market share is less than $1 / 2$ ), when retailers have capital constraints and take bank financing, the wholesale prices of manufacturer are less than those of retailers without capital constraints. On the contrary, when the retailer has capital constraint and adopts bank financing, the wholesale price of manufacturer 2 is higher than that of retailer without capital constraint. In the same higher market share environment (the market share is more than half), when the retailer has capital constraint and adopts bank financing, the wholesale price of manufacturer 2 is lower than that of the retailer with no capital constraint. On the contrary, when the retailer has capital constraint and adopts bank financing, the wholesale price of manufacturer 2 is higher than that of the retailer with no capital constraint. This is a change in the market share position of manufacturer 1 and manufacturer 2, that is, when the market share is less than half, the pricing strategy of manufacturer 1 is consistent with the pricing strategy of manufacturer 2 when the market share is more than one half. When the market share is more than half, the pricing strategy of manufacturer 1 is consistent with the pricing strategy of manufacturer 2 when the market share is less than one half. They can achieve roles reversed. 


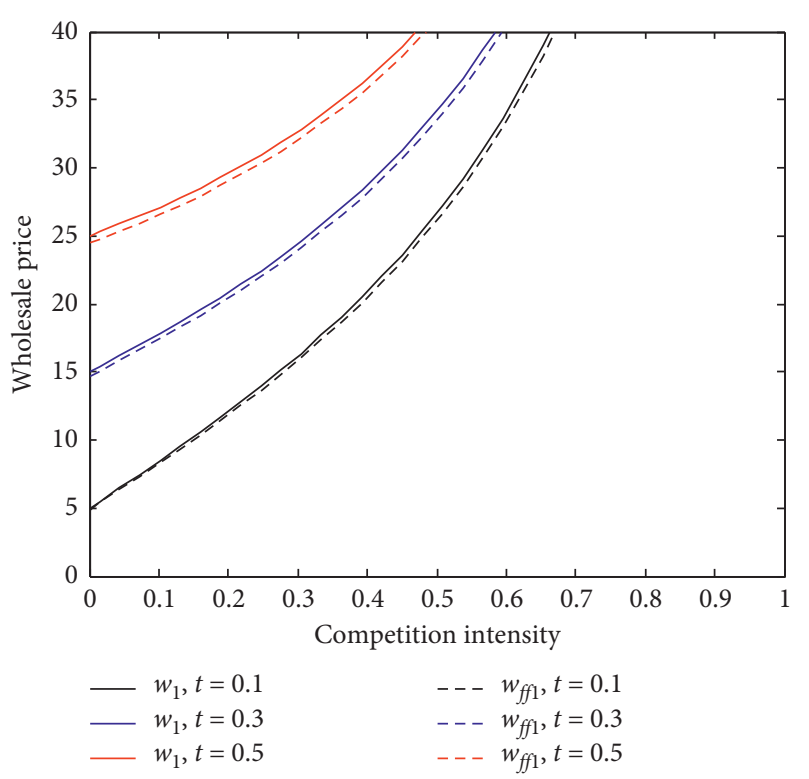

(a)

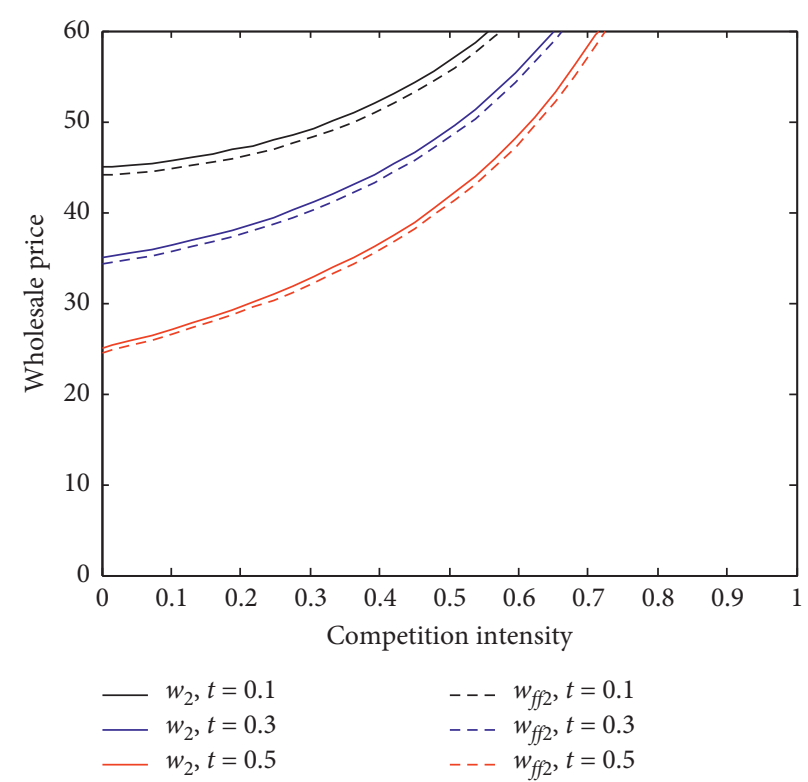

(b)

Figure 2: The relationship between wholesale prices of manufacturer 1 and manufacturer 2 and competition intensity in two competitive supply chains with or without capital constraints.

Figure 3 shows that in the different market share environments, whether the retailer in the two competitive supply chain systems has no financial constraint or the retailer has financial constraint and adopts external bank financing, the retail sales price on their respective chains is an increasing function of the intensity of competition between retailers and sales price increases with the increase of the competition intensity. For different market shares, the selling price of retailer 1 will increase with the increase of market share and the pricing will be higher and higher under the condition that the competition intensity among retailers is certain. The selling price of retailer 2 will decrease with the increase of market share under the condition that the competition intensity between retailers is certain, and the pricing becomes lower and lower. Finally, when two retailers share the market share equally, the selling price of two retailers tends to be the same. For retailers with no financial constraints and with capital constraints and taking bank financing, we found that in the same market share environment, whether its market share is less than half or the market share is more than half, the sales price of retailer with financial constraints and taking bank financing is the same as the sales price of retailer without financial constraint, which has nothing to do with the retailer without financial constraint or with financial constraint and taking bank financing.

Figure 4 shows that under the different market environments, whether the retailer in the two competition of supply chain system has no financial constraints or has financial constraint and takes external financing, the expected profit of retailers in their respective chains is an increasing function of the competition intensity between retailers and expected profits of retailers increased with the increase of the competition intensity. For different market shares, the expected profit of retailer 1 will increase with the increase of market share and profit will be higher and higher under certain competition intensity among retailers. The expected profit of retailer 2 will decrease with the increase of market share under certain competition intensity between retailers, and the profit will become lower and lower. Finally, when two retailers share the market share equally, the expected profit of two retailers tends to be the same. For retailers with no financial constraint and with financial constraints and taking bank financing, we found that in the same market share environment, whether its market share is less than half or the market share is more than half, the expected profits of retailer 1 with financial constraints and taking bank financing are greater than retailer 1 without financial constraints. Similarly, when the retailer has capital constraint and adopts bank financing, the expected profit of retailer 2 is all higher than that of retailer 2 when the retailer has no capital constraint. Instead, capital constraint can increase the expected profit of retailer.

Figure 5 shows that in the different market share environments, whether the retailer in the two competition of supply chain system has no financial constraints or has financial constraints and adopts external financing, expected profit of the manufacturer in the respective chain is an increasing function of the intensity of competition between retailers and the expected profit of manufacturers increases with the increase of the competition intensity. For different market shares, the expected profit of manufacturer 1 will increase with the increase of market share and profit will be higher and higher under certain competition intensity among retailers. The expected profit of manufacturer 2 will decrease with the increase of market share under certain competition intensity between retailers, and the profit will become lower and lower. Finally, when the two 


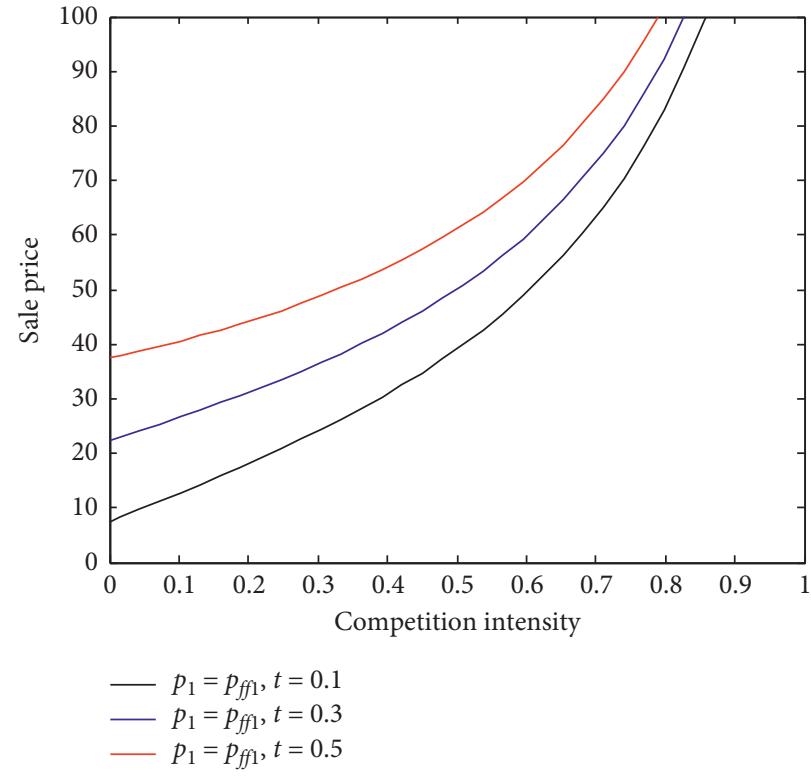

(a)

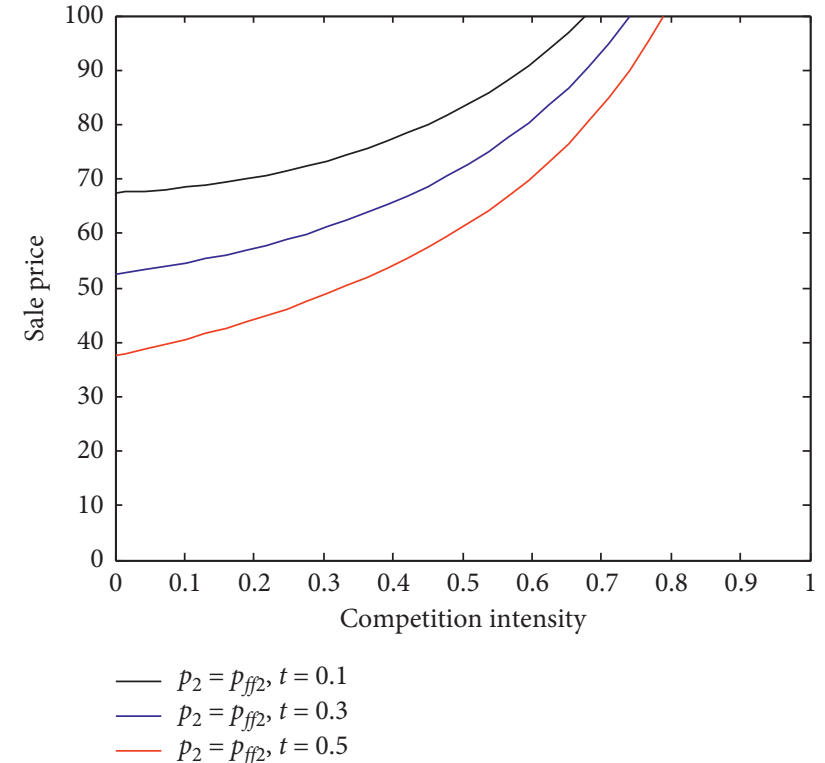

(b)

FIgURE 3: The relationship between the sales price and competition intensity of retailer 1 and retailer 2 in two competing supply chains with or without capital constraints.

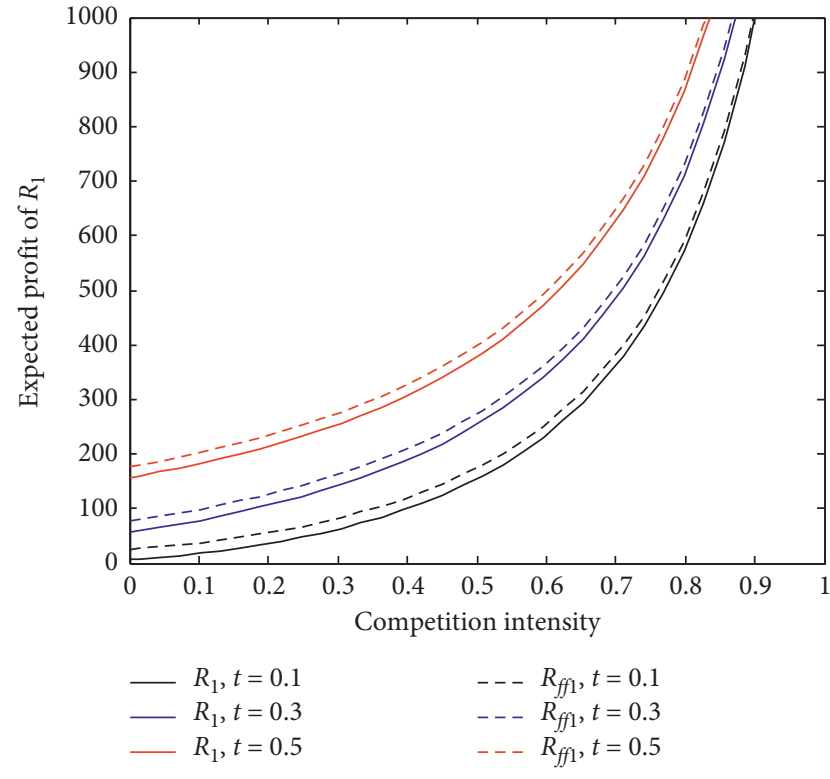

(a)

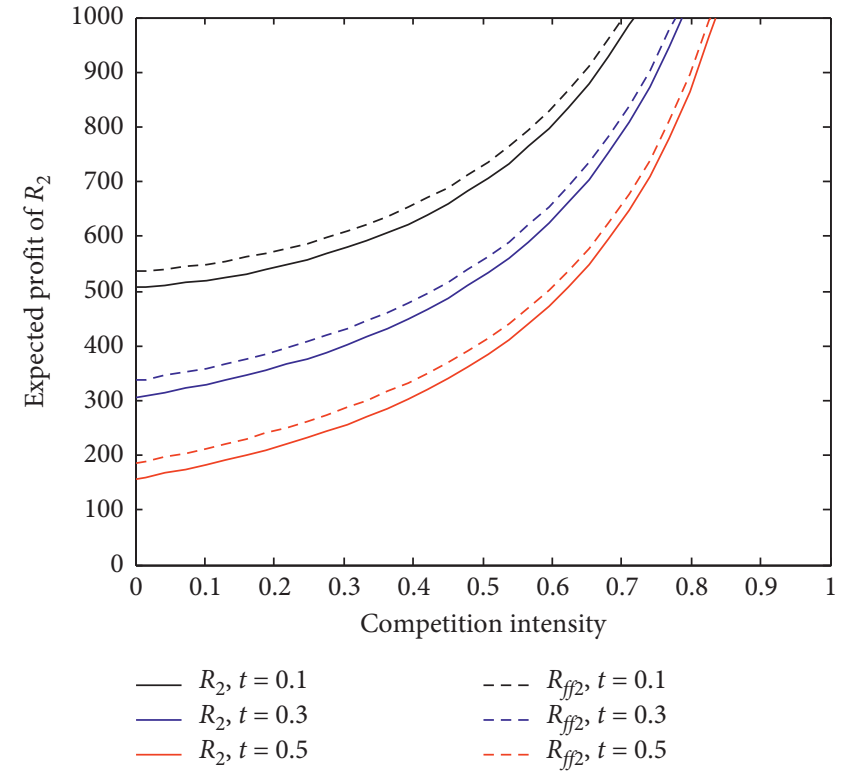

(b)

FIgURE 4: The relationship between expected profit and competition intensity of retailer 1 and retailer 2 in two competing supply chains with or without capital constraint.

manufacturers share the market share equally, the expected profit of the two manufacturers tends to be the same. For retailers with no capital constraints and with financial constraints and taking bank financing, we found that in the same market share environment, whether its market share is less than half or the market share is more than half, when retailers have financial constraints and take bank financing, expected profits of manufacturer 1 are less than expect profits of manufacturer 1 when retailers have no financial constraints. Similarly, when retailers have capital constraints and adopt bank financing, the expected profit of manufacturer 2 is all smaller than that of manufacturer 2 when retailers have no capital constraints, and capital constraints are not conducive to manufacturers' expected profit.

Figure 6 shows that in different market share environments, whether the retailer in the two competitions of supply 


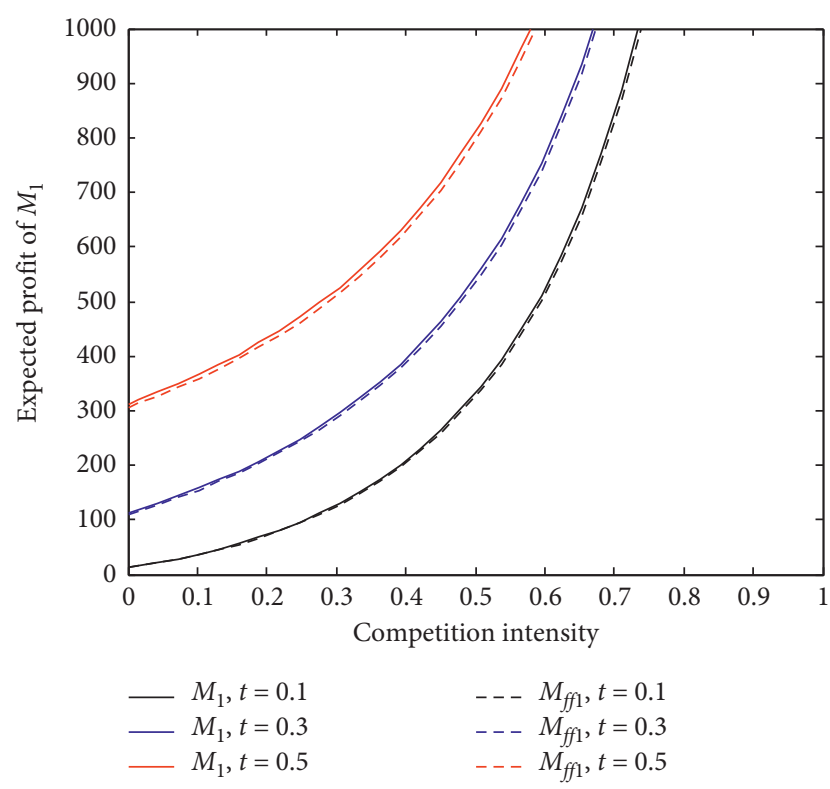

(a)

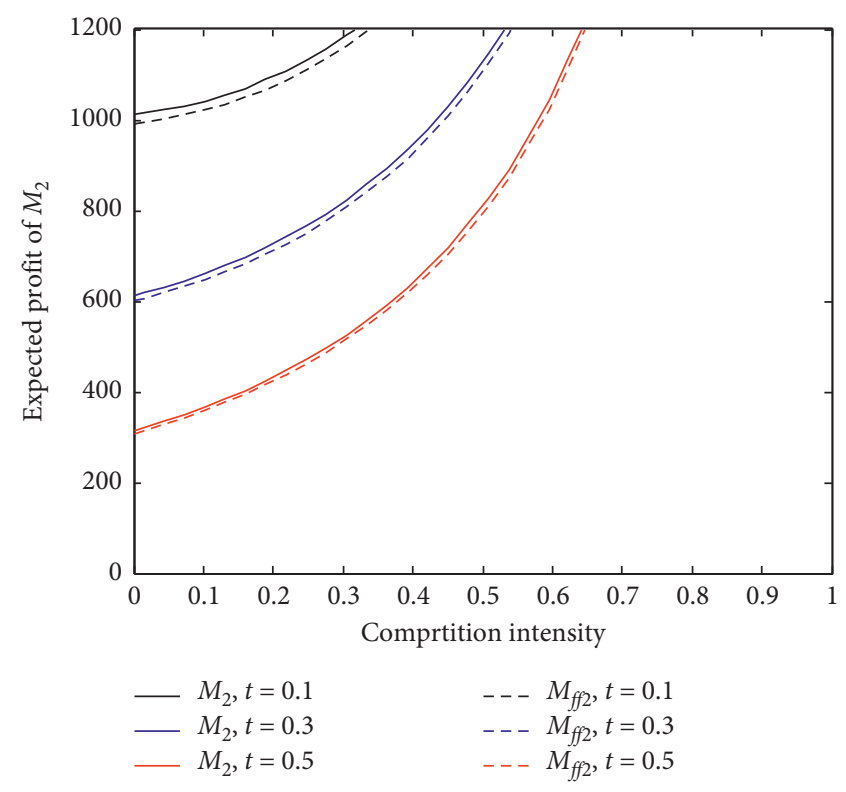

(b)

FIgURE 5: The relationship between the expected profit and competition intensity of manufacturer 1 and manufacturer 2 in two competitive supply chains with or without capital constraint.

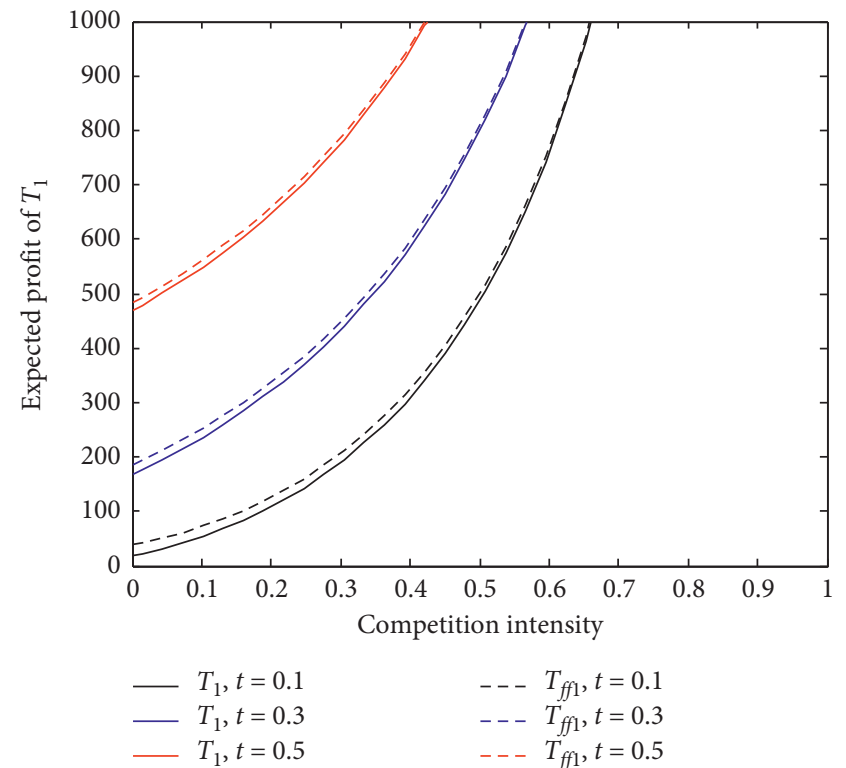

(a)

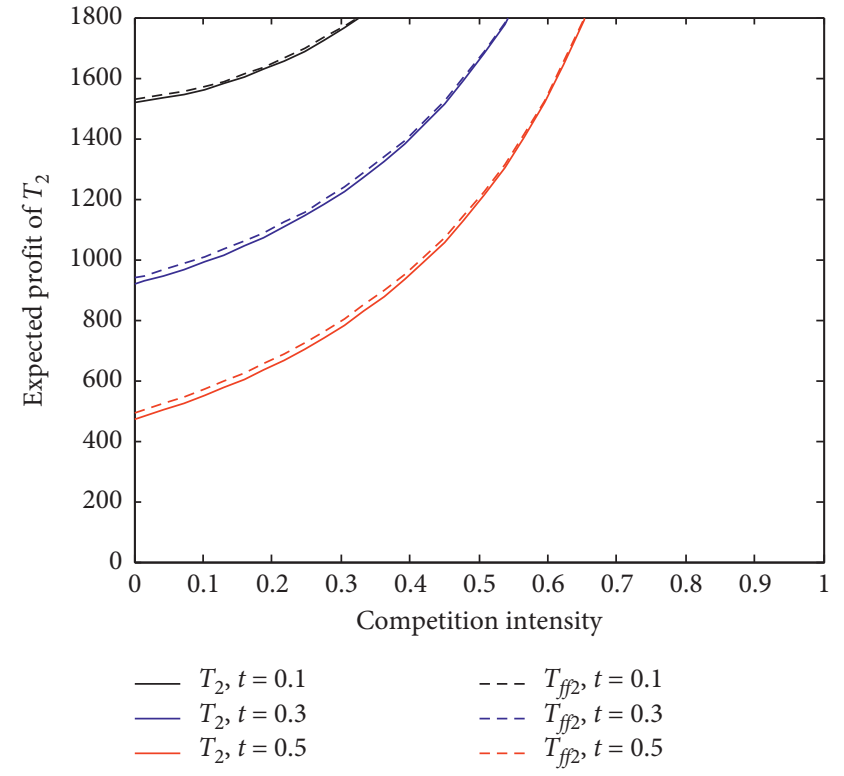

(b)

FIgURE 6: The relationship between expected profit and competition intensity of two competing supply chain systems (system 1 and system 2) with or without capital constraint.

chain system has no financial constraints or has financial constraint and adopts external financing, the expected profit of the respective chain system is an increasing function of the intensity of competition between retailers and the expected profit of manufacturers increases with the increase of the competition intensity. For different market shares, the expected profit of system 1 will increase with the increase of market share and profit will be higher and higher under certain competition intensity among retailers. The expected profit of system 2 will decrease with the increase of market share under certain competition intensity between retailers, and the profit will become lower and lower. Finally, when the two systems share the market share equally, the expected profit of the two systems tends to be the same. For retailers with no financial constraints and with financial constraints and taking bank financing, we found that in the same market 
share environment, whether its market share is less than half or the market share is more than half. Compared with the expected profit of the first supply chain when the retailer adopts bank financing and the retailer has full funds, the expected profit is large for the bank financing. Similarly, when the retailers have capital constraint and adopt bank financing, the expected profit of system 2 is all higher than that of system 2 when the retailer has no capital constraint, and the capital constraint is beneficial to the increase of the expected profit of the system.

\section{Conclusions}

In this paper, two exclusive supply chains are constructed, each of which is composed of a manufacturer and a retailer. There are two situations of the capital of retailer. In one case, the two retailers have no capital constraint, and in the other case, the two retailers on both chains have capital constraint. There is market competition between the two retailers, who sell alternative products. They are both rational and can maximize their expected profits. Under different competition intensities, the manufacturer's wholesale price and the retailer's selling price are different when the retailer has capital constraint or not. The results show that once the market share among retailers is fixed, the wholesale price of suppliers and the selling price of retailers will increase with the increase of competition intensity, regardless of whether the retailer has capital constraints or not. The higher the competition intensity among retailers is, the better the expected profit of each member of the supply chain and the system will be. Another conclusion is that the external bank financing mode has no effect on the sales price of financially constrained retailers when they adopt bank financing. But it will influence the whole price of manufacturer. The wholesale price of the manufacturer in the first chain is higher than the wholesale price of the manufacturer without financial constraints, and the wholesale price of the manufacturer in the second chain is lower than the wholesale price of the manufacturer without financial constraints.

This paper analyzes the pricing decision of the competitive supply chain of the financial constraint retailer's bank financing, only including the bank financing into the competitive supply chain system. It considers the exogenous bank financing interest rate, and then bank's financing rate can be used as decision-making variable. Banks are also regarded as a part of the competitive supply chain system. For example, in China, Shanghai Volkswagen $4 \mathrm{~S}$ shops have their own loan bank. And we assume that bank financing is infinite, that is, banks can provide as much capital as capital-constrained retailers lack. For small and medium-sized enterprises, banks may meet this kind of situation. However, large enterprises need more capital, which leads to the lack of liquidity after bank loans. Later, we can discuss whether the intensity of competition between retailers affect the bank's financing rate or not and whether the bank financing rate also affects the performance of the members and systems in the competitive supply chain. This will be our further research direction in the future.

\section{Appendix}

Proof of Proposition 1. For $p_{1}^{M M^{*}}<p_{2}^{M M^{*}}$ in Proposition 1, we can subtract (7) and (8) above, namely (7) and (8), and then can be obtained:

In equations (7) and (8), because $b \in(0,1)$ then $\left(b^{2}-3\right)<0, \quad(b+2)>0$, and $\left(2 b^{2}-b-4\right)<0$, the value relationship of $p_{1}^{M M^{*}}-p_{2}^{M M^{*}}$ depends on the value of $(2 t-1)$. When $t=(1 / 2), 2 t-1=0$. So, when $t \in(0,(1 / 2))$, $p_{1}^{M M^{*}}-p_{2}^{M M^{*}}<0$, i.e. $p_{1}^{M M^{*}}<p_{2}^{M M^{*}}$. When $t \in((1 / 2), 1)$, $p_{1}^{M M^{*}}-p_{2}^{M M^{*}}>0$, i.e., $p_{1}^{M M^{*}}>p_{2}^{M M^{*}}$.

$w_{1}^{M M^{*}}<w_{2}^{M M^{*}}$ in Proposition 1, we can subtract (5) and (6), namely, (5) and (6), and then get:

In equations (5) and (6), because $b \in(0,1), b-2<0$, and $2 b^{2}-b-4<0$, the value relationship of $w_{1}^{M M^{*}}-$ $w_{2}^{M M^{*}}$ depends on the value of $(2 t-1)$. When $t=(1 / 2)$, $2 t-1=0$, so when $t \in(0,(1 / 2)), w_{1}^{M M^{*}}-w_{2}^{M M^{*}}<0$, i.e., $w_{1}^{M M^{*}}<w_{2}^{M M^{*}}$; when $t \in((1 / 2), 1), w_{1}^{M M^{*}}-w_{2}^{M M^{*}}>0$, i.e., $w_{1}^{M M^{*}}>w_{2}^{M M^{*}}$.

Thus, Proposition 1 is proved.

\section{Data Availability}

The data are only based on an assumption of general market reality to verify the correctness of my model establishment and verification analysis.

\section{Conflicts of Interest}

The author declares that there are no conflicts of interest.

\section{Acknowledgments}

This research was supported by the Major Project of Jiangsu Business Accounting Society "Research on problems and countermeasures of internal control in colleges and universities" under grant no. 2016JSSYKJ105, the project of Chinese Society of Educational Accounting "Financial problems and solutions in colleges and universities-from the perspective of internal control" under grant no. GS2019Z04, and the project of general project of philosophy and social sciences in colleges and universities of Jiangsu Provincial Department of Education "A study of financial development on economic growth in Jiangsu Province" under grant no. 2019SJA0936.

\section{References}

[1] M. S. Zhou and B. Dan, "Coordinating a group purchasing supply chain under economies of scale and competition," Chinese Journal of Management Science, vol. 25, no. 2, pp. 98-110, 2017.

[2] Gome, Suning and Yongle have the highest asset-liability ratio (96.77\%). http://www.linkshop.com.cn/ (kwthrmauciseeriqsdu1ui55)/web/Article_News.aspx? ArticleId $=62837$.

[3] G. Bounds, "Pen maker struggles with too much demand," The Wall Street Journal, vol. 14, pp. 1-4, 2006.

[4] X. Xu and J. R. Birge, Joint Production and Financing Decisions: Modeling and Analysis. Working Paper, Northwestern University, Evanston, IL, USA, 2004. 
[5] X. H. Yi and Z. F. Zhou, "Research on the value ratio of bank loans based on supply chain finance," China Management Science, vol. 20, no. 1, pp. 102-108, 2012.

[6] J. A. Buzacott and R. Q. Zhang, "Inventory management with asset-based financing," Management Science, vol. 50, no. 9, pp. 1274-1292, 2004.

[7] Y. Xu and J. Zhang, On the Selection of Supply Chain Coordinating Contracts: The Role of Capital Constraints. Working Paper, University of Miami, Miami, FL, USA, 2006.

[8] X. F. Chen and W. J. Ying, "Financing service for the healthsector supply chain," Working Paper Series, Stem School of Business in New York University, New York, NY, USA, 2007.

[9] M. Dada and Q. H. Hu, "Financing newsvendor inventory," Operations Research Letters, vol. 36, no. 5, pp. 569-573, 2008.

[10] X. F. Chen, D. L. Zhu, and W. J. Ying, "Financing and operation decisions in budget-constrained supply chain," Journal of Management Science in China, vol. 11, no. 3, pp. 70-77, 2008.

[11] Y. Y. Zhang and J. B. Li, "Optimal inventory management under inventory financing," Systems Engineering Theory and Practice, vol. 28, no. 9, pp. 29-38, 2008.

[12] N. R. S. Raghavan and V. K. Mishra, "Short-term financing in a cash-constrained supply chain," International Journal of Production Economics, vol. 43, no. 1, pp. 993-1001, 2009.

[13] G. Lai, L. G. Debo, and K. Sycara, "Sharing inventory risk in supply chain: the implication of financial constraint," Omega, vol. 37, no. 4, pp. 811-825, 2009.

[14] C. H. Lee and B. D. Rhee, "Coordination contracts in the presence of positive inventory financing costs," International Journal of Production Economics, vol. 124, no. 2, pp. 331-339, 2010.

[15] P. Kouvelis and W. Zhao, "The newsvendor problem and price-only contract when bankruptcy costs exist," Production and Operations Management, vol. 20, no. 6, pp. 921-936, 2011.

[16] N. R. S. Raghavan and V. K. Mishra, "Short-term financing in a cash-constrained supply chain," International Journal of Production Economics, vol. 134, no. 2, pp. 407-412, 2011.

[17] B. Jing, X. Chen, and G. G. Cai, "Equilibrium financing in a distribution channel with capital constraint," Production and Operations Management, vol. 21, no. 6, pp. 1090-1101, 2012.

[18] D. Y. Yu and J. W. Luo, "Reverse auction under budget constraints," Journal of Systems \& Management, vol. 21, no. 2, pp. 206-210, 2012.

[19] Q. H. Lu, L. F. Zeng, and W. H. Zhou, "Research on decisionmaking and value of supply chain financing with accounts receivables," Journal of Management Science in China, vol. 15, no. 5, pp. 10-18, 2012.

[20] C. Z. Ariel, W. S. Ralf, and P. S. Margarita, "Single product, finite horizon, periodic review inventory model with working capital requirements and short-term debt," Computers and Operations Research, vol. 40, no. 12, pp. 2940-2949, 2013.

[21] N. Yan and B. Sun, "Coordinating loan strategies for supply chain financing with limited credit," OR Spectrum, vol. 35, no. 4, pp. 1039-1058, 2013.

[22] N. Yan, H. Dai, and B. Sun, "Optimal bi-level Stackelberg strategies for supply chain financing with both capital-constrained buyers and sellers," Applied Stochastic Models in Business and Industry, vol. 30, no. 6, pp. 783-796, 2014.

[23] Z. R. Wang, X. C. Tian, and X. H. Chen, "Game theory analysis on accounts receivable financing of supply chain financing system considering implicit equity stake," Chinese Journal of Management Science, vol. 23, no. 9, pp. 1-8, 2015, in Chinese.
[24] P. Kouvelis and W. Zhao, "Supply chain contract design under financial constraints and bankruptcy costs," Management Science, vol. 62, no. 8, pp. 2341-2357, 2016.

[25] H. J. Peng, "Mortgage financing strategy with accounts receivable in supply chain with uncertain yields," Journal of Systems \& Management, vol. 25, no. 6, pp. 1163-1169, 2016.

[26] X. Q. Xu and Z. H. Ma, "The supply chain financing decision of third- party logistics participation considering supplier competition," China Population, Resources and Environment, vol. 27, no. 11, pp. 91-94, 2017.

[27] Q. Lin and Q. Xu, "Coordination research of the option contract under advance payment financing," Operations Research and Management Science, vol. 27, no. 6, pp. 172-183, 2018.

[28] T. W. McGuire and R. Staelin, "An industry equilibrium analysis of downstream vertical integration," Marketing Science, vol. 2, no. 2, pp. 161-191, 1983.

[29] K. S. Moorthy, "Strategic decentralization in channels," Marketing Science, vol. 7, no. 4, pp. 335-355, 1988.

[30] M. Trivedi, "Distribution channels: an extension of exclusive retailership," Management Science, vol. 44, no. 7, pp. 896-909, 1998.

[31] T. Boyaci and G. Gallego, "Supply chain coordination in a market with customer service competition," Production and Operations Management, vol. 13, no. 1, pp. 3-22, 2004.

[32] A. Y. Ha and S. Tong, "Contracting and information sharing under supply chain competition," Management Science, vol. 54, no. 4, pp. 701-715, 2008.

[33] T. Xiao and D. Yang, "Risk sharing and information revelation mechanism of a one-manufacturer and one-retailer supply chain facing an integrated competitor," European Journal of Operational Research, vol. 196, no. 3, pp. 1076-1085, 2009.

[34] Q. H. Lu and D. L. Zhu, "Research on equilibriums and coordination strategies of supply chain with quality and price competition," Journal of Management Sciences in China, vol. 12, no. 3, pp. 56-64, 2009.

[35] B. Xu and G. Sun, "Supply chain competition between two SCs and SC coordination modes for shelf-display-quantity," Journal of Industrial Engineering/Engineering Management, vol. 25, no. 1, pp. 197-202, 2011, in Chinese.

[36] A. Y. Ha, S. Tong, and H. Zhang, "Sharing demand information in competing supply chains with production diseconomies," Management Science, vol. 57, no. 3, pp. 566-581, 2011.

[37] X. Ai, J. Chen, and J. Ma, "Contracting with demand uncertainty under supply chain competition," Annals of Operations Research, vol. 201, no. 1, pp. 17-38, 2012.

[38] D. Wu, "Coordination of competing supply chains with newsvendor and buyback contract," International Journal of Production Economics, vol. 144, no. 1, pp. 1-13, 2013.

[39] T. Xiao, J. Shi, and G. Chen, "Price and leadtime competition, and coordination for make-to-order supply chains," Computers \& Industrial Engineering, vol. 68, pp. 23-34, 2014.

[40] Y. Fang and B. Shou, "Managing supply uncertainty under supply chain cournot competition," European Journal of Operational Research, vol. 243, no. 1, pp. 156-176, 2015.

[41] M. R. Amin-Naseri and M. A. Khojasteh, "Price competition between two leader-follower supply chains with risk-averse retailers under demand uncertainty," The International Journal of Advanced Manufacturing Technology, vol. 79, no. 1-4, pp. 377-393, 2015.

[42] X. Z. Zhang, C. Liu, and R. L. Zhang, "Pricing and coordination of dual-channel supply chain based on alternative 
product competition," Soft Science, vol. 30, no. 3, pp. 121-125, 2016.

[43] C. Y. Sun and Y. Y. Qiao, "Pricing strategy of dual channel supply chain under service competition," Science and Technology and Management, vol. 18, no. 5, pp. 17-20, 2016.

[44] K. Li, W. Li, and G. An, "Manufacturer pricing strategies in the context of chain and chain competition," Journal of Systems Management, vol. 26, no. 4, pp. 771-778, 2017.

[45] C. Zheng, X. Z. Ai, X. J. Li, and G. P. Wang, "Selection of two pricing contracts for extended supply chain service of competitive retailers," Journal of Systems Engineering, vol. 33, no. 5, pp. 674-686, 2018.

[46] C. M. Wei, Z. P. Li, and Q. Fan, "Research on pricing decision of dual-channel supply chain with multi-competitive retailers under different game frameworks," Operational Research and Management, vol. 27, no. 6, pp. 63-74, 2018. 